\title{
Revizyon İmar Planlarına En Küçük Kareler Yöntemi İle İlçe Düzeyinde Bakış, Selim İlçesi Kars Örneği
}

\author{
Selim Taşkaya ${ }^{a 1 *}$ \\ ${ }^{a}$ Artvin Meslek Yüksekokulu, Mimarlık ve Şehir Planlama Bölümü, Artvin, Türkiye \\ İstanbul Sabahattin Zaim Üniversitesi Fen Bilimleri Enstitüsü Dergisi (2021) 3 (2): 138-148 \\ https://doi.org/10.47769/izufbed.912142 \\ (iD) $O R C I D{ }^{1} 0000-0002-4290-3684$

\section{YAYIN BİLGISİ} \\ Yayın geçmiși: \\ Gönderilen tarih: 09 Nisan 2021 \\ Kabul tarihi: 19 Nisan 2021 \\ Anahtar kelimeler: \\ Revize imar planı \\ En küçük kareler yöntemi \\ Selim ilçesi

\begin{abstract}
ÖZET
İmar planları, hem mevcut mekansal sorunların tespit edilmesi hem de gelecekte ortaya çıkacak mekansal ihtiyaçların giderilmesi amacıyla yapılan araştırma ve planlama çalışması ile yerleşimin sosyo-ekonomik, demografik ve fiziksel yapısı göz önünde bulundurularak, bir kentsel kimlik oluşturulması, öngörülen ekonomik gelişme senaryosuna uygun olarak arazi kullanım kararlarının üretilmesi ve kentsel yaşam standartlarına uygun, yaşanabilir, sağlıklı bir kentin oluşturulmasını amaçlayan planlardır. Kendi içerisinde farklı çeşitleri olmakla birlikte uygulama imar planı olarak il, ilçe, belde gibi belediyeleri olan nüfusun fazla olduğu yerleşim yerlerinde ihtiyaca cevap verecek geniş çaplı plan revize imar planlarıdır. Çalışmamız Kars İli Selim ilçesinde en küçük kareler yöntemi kullanılarak regresyon analizi ile Selim yerleşmesinin kentsel alan ihtiyacı ve gelişme potansiyeli ortaya çıkarılmıştır. Öngörülen nüfus projeksiyonuna ve hedeflenen sektörel gelişmelere göre plan alternatifleri üretilip, alınan plan kararları doğrultusunda yürürlükteki mevcut 1/5000 Ölçekli Nazım İmar Planı ve 1/1000 Ölçekli Uygulama İmar Planı revize edilerek kentsel gelişim
\end{abstract} \\ yönü doğrultusunda belirlenecek ilave alanlar için imar planı çalışması irdelenmiştir.
}

\section{Regional Wiev to Revision Zoning Plans With The Smallest Squares Method, Selim District Kars Example}

\begin{tabular}{l} 
ARTICLE INFO \\
\hline Article history: \\
Received: 09 April 2021 April 2021 \\
Accepted: 19 An \\
Key words: \\
Revised zoning plan \\
Least squares method \\
Selim district
\end{tabular}

\section{ABSTRACT}

The zoning plans are designed to create an urban identity, taking into account the socio-economic, demographic and physical structure of the settlement, with the research and planning studies conducted in order to determine the existing spatial problems and to eliminate the spatial needs that will arise in the future, land use in accordance with the envisaged economic development scenario. These are the plans that aim to produce the decisions and create a livable and healthy city in accordance with urban life standards. Although there are different types within itself, the implementation development plan is the revised development plans that will meet the needs in the settlements with high population such as provinces, districts and towns. In our study, the urban area need and development potential of Selim settlement was revealed by regression analysis using the least squares method in Selim district of Kars province. Plan alternatives were produced according to the projected population projection and targeted sectoral developments, and the current 1/5000 Scaled Master Zoning Plan and 1/1000 Scaled Implementation Zoning Plan were revised in line with the plan decisions, and zoning plan studies were carried out for additional areas to be determined in line with the urban development direction.

\section{Giriş}

Planlama, kavram olarak belli bir zaman diliminden daha ileriye doğru düşünülen, tasarlanan, olabilirlikleri, olasılıkları irdeleyen, karşılaştıran ve değerlendiren bir düşünce biçimidir (Aydemir, 2004). Kavramsal olarak belirlenen bir amaca ulaşabilmek için, harekete geçmeden önce, yapılan hazırlıklar, karar verme ve seçim yapma süreci olup planlama, harekete-eyleme yön verecek olan düşünce sistemini oluşturur ve böylece eyleme yön veren kurumsal teorik, varsayım yapıyı getirir, düşünce tarzını saptar şeklinde tanımlanabilir (Suher. 1996). Kent planlaması ise, kentin/kentlerin mevcut problemlerinin ve büyüme eğilimlerinin verdiği sinyaller doğrultusunda kentin, önceden belirlenen bir süre için ulaşacağ1 büyüklük, işlevsel ilişkilerin, ulaşım ve iletişim, sosyal ve fiziksel dokusunun tasarlanması olarak tanımlanan bir karar verme, değerlendirme süreci olup kavramsal bir sistemdir. Plan, planlama sürecinde, yapılan değerlendirmeler sonucu varılan bir kararın ifade şekli, uygulanması için bir araç ve planlama kentin gelecekteki büyümesi, düzenlenmesi için yapılan tüm çalışmaların teferruatlı bir raporla ve ölçekli, ayrıntılı şekilde, paftalarla ifadesi olup, tasarım, anlatım ve uygulama aracıdır (Gülaç, 2015). İmar Kanunu'nun 5. maddesinin 3. fikrasina ve Plan Yapımına Ait Esaslara Dair Yönetmeliğin 3. maddesinin 1. fikrasına göre uygulama imar planı, onaylı halihazır haritalar üzerine varsa kadastral durumu işlenmiş olan ve nazım imar planına uygun olarak hazırlanan ve çeşitli bölgelerin yapı adalarını, bunların yoğunluk ve düzenini, yolları ve uygulama için gerekli imar uygulama programlarına esas olacak uygulama etaplarını ve esaslarını ve diğer bilgileri ayrıntıları ile gösteren ve 1/1.000 ölçekte düzenlenen raporuyla bir bütün olan plandır (Karaman, 2012). Uygulama imar planlarında çeşitli kent bölgelerinin yapı adaları, yolları, yapı adalarının yoğunluk düzeni ve imar uygulama planlarına temel oluşturacak uygulama aşamaları gösterilir (Tazegül, 2010). Diğger bir ifadeyle; ulaşım kanallarının yön ve genişliklerini, oturma ve çalışma alanlarının kentteki 
yerlerini, kenti oluşturan öteki öğelerin mekandaki konumunu ve kentin ne yönde gelişeceğini gösteren belgelerdir (Doğan ve Ergingöz, 1997). Aynı planlarda altyapı tesisleriyle uygulama ilişkilerinin ayrıntılarına ve yapının inşasında uyulması gereken kurallara da yer verilir (Karaman, 2012). Plan Yapım Esaslarına Dair Yönetmeliğe göre revizyon imar planı; nazım veya uygulama imar planlarının ihtiyaca cevap vermediği ve uygulamada problem olan durumlarda; planın tümünün veya büyük bir kısmının plan yapım tekniklerine uyularak yenilenmesi sonucu elde edilen plan türüdür. $\mathrm{Bu}$ plan her tür ve ölçekteki planın ihtiyaca cevap vermediği, uygulanmasının mümkün olmadığı veya sorun yarattığı durumlar ile üst ölçek plan kararlarına uygunluğun sağlanması amacıyla planın tamamının veya plan ana kararlarını etkileyen bir kısmının yenilenmesi sonucu elde edilmektedir (Karaman, 2012).

\section{Materyal ve Yöntem}

2.1 En Küçük Kareler Metodu

Bilimsel çalışmalarda, genellikle ya özellikler arası ilişki, yada ilgilenilen özellik bakımından faktör olarak nitelendirilen gruplar arası fark olup olmadığı araştırılır. İlgilenilen değişkenlerden birisinin cevap değişkeni (bağımlı değişken), diğerinin veya diğerlerinin de açıklayıcı (bağımsız) değişken olması durumunda, cevap değişkenini tahmin etmek üzere kurulan eşitlik, regresyon veya tahmin denklemi olarak adlandırılır. Regresyon analizi ise bu denklemdeki katsayıların bulunması ve sonuçların yorumlanması işlemlerini kapsar. Yaygın olarak kullanılan standart regresyon analizinin uygulanabilmesi için, cevap değişkeni ve açıklayıcı değişkenlere ait bazı varsayımların veya ön şartların sağlanması gerekir (Demir, 2019). En küçük kareler yöntemi, tek bir eşitlik yöntemi olup, aracı değişkenler modeli tahmininde kullanıldığı gibi bir eşitlik sistemindeki tüm eşitliklere de ayrı ayrı uygulanabilir. Bu durum, değişkenler arası iki yönlü ilişkinin tahmini için kolaylık sağlar. Yöntemin hesaplaması kolaydır ve sayısal optimizasyon algoritmalarının kullanılmasını gerektirmez. Yöntem genel olarak iki aşamayı içerir. Birinci aşamada, aracı değişken kullanılarak yeni değişken elde edilir. İkinci aşamada ise problemli açıklayıcı değişkenin gerçek değerleri yerine kullanılan değişkenden yararlanılarak cevap değişkeni için standart regresyon analizi yöntemi uygulanır (Demir, 2019).

Çizelge 1. En küçük kareler formül gösterimi (Selim İmar planı Açılama Raporu, 2016).

\begin{tabular}{ll}
\hline \multicolumn{3}{c}{ En Küçük Kareler Metodu } \\
\hline Doğrusal & Logaritmik \\
$\mathrm{P}_{\mathrm{t}}=\mathrm{a}+$ & $\log \mathrm{P}_{\mathrm{t}}=\log \mathrm{a}+\log \mathrm{bx}$ \\
$\mathrm{bx}$ & $\log \mathrm{a}=\log \mathrm{P} / \mathrm{n}$ \\
$\mathrm{a}=\mathrm{P} / \mathrm{n}$ & \\
$\mathrm{b}=\mathrm{Px} /$ & $\log \mathrm{b}=\log \mathrm{Px} / \mathrm{x}^{2}$ \\
$\mathrm{x}^{2}$ &
\end{tabular}

\begin{tabular}{ll}
\hline $\begin{array}{l}\text { Üssel } \\
\text { Artış }\end{array}$ & Bileşik Faiz \\
\hline $\mathrm{P}_{\mathrm{t}}=\mathrm{P}_{\mathrm{o}} \mathrm{e}^{\mathrm{rt}}$ & $\mathrm{P}_{\mathrm{t}}=\mathrm{P}_{\mathrm{o}}(1+\mathrm{r})^{\mathrm{t}}$ \\
& \\
$\mathrm{P}:$ Gözlem Y111 Nüfusu & $\mathrm{n}:$ Gözlem Y11 Sayısı \\
$\mathrm{P}_{\mathrm{t}}:$ Projeksiyon Y11 & \\
Nüfusu & $\mathrm{r}:$ Ortalama Nüfus Artış1 \\
& $\mathrm{t}: \mathrm{P}_{\mathrm{t}} \mathrm{Y}_{11}-\mathrm{P}_{\mathrm{o}}$ \\
$\mathrm{P}_{\mathrm{o}}: 2010$ Y11 Nüfusu & $\mathrm{Y}_{1} 11$ \\
\hline
\end{tabular}

$\mathrm{Y}=\mathrm{B}_{0}+\mathrm{B}_{1} \mathrm{X}+\mathrm{e}$ olarak ifade edilen eşitlik; $\mathrm{X}$ ve $\mathrm{Y}$ değişkenlerinin ait olduğu popülasyonlar için geçerlidir. İstatistik çalışmaların çoğunda olduğu gibi regresyon analizinde de popülasyonun tamamına ait verilere ulaşılamadığından, bu popülasyondan alınan örneklem verileriyle analiz yapılır. Örneklem verileri kullanılarak popülasyon parametreleri olan $\mathrm{B}_{0}$ $\mathrm{veB}_{1}$ 'in kestirimlerini elde edebilmek için en küçük kareler yönteminden yararlanılır. X ve Y değerleri için (X1 ,Y1 ), (X2, Y2), ...., ( Xk, Yk) ikili gözlemleri bir örneklem oluşturur. Bunlar yardımıyla $Y=B_{0}+B_{1} X+e$ eşitliğin katsayılarını bulma olanağı yoktur. Örnekten hareketle bunlar tahmin edilebilir (Montgomery ve Peck, 1992).

\subsection{Selim İlçesi Nüfus Projeksiyonu ve Revize İmar planı Üretimi}

Selim; Doğu Anadolu Bölgesi'nin Kuzey Doğu Anadolu Bölümünde, idari yönden Kars iline bağlı bir yerleşimdir. Yerleşme Kars kent merkezinin yaklaşık $31 \mathrm{~km}$ güney batısında yer almaktadır. Nüfusu ve büyüklüğü

bakımından Selim İlçesi, Sarıkamış'tan sonra dördüncü sıradadır. Selim, 1957 y1lında belediye statüsüne kavuşmuştur. Denizden yüksekliği 1847 metredir. Selim İlçesi'nin yüzölçümü $1011 \mathrm{~km}^{2}$ olup, $40^{\circ} 27^{\prime}$ kuzey enlemi, $42^{\circ} 47^{\prime}$ doğu boylamı konumlanmaktadır. 2014 yılında yapılan Adrese Dayalı Nüfus Kayıt Sistemi verilerine göre ilçenin merkez nüfusu 5152 kişi, toplam nüfusu 24924 kişidir (TÜiK, 2019).

Selim'in planlama çalışmalarında hedef yılı olan 2035 yılına göre hesaplanan projeksiyon nüfusları 3369 ile 7584 kişi arasında değişmektedir. Yapılan nüfus projeksiyonlarının ortalama değeri alındığında 5420 kişi olmaktadır. Planlama dönemi içerisinde tarım-hayvancılık, ticaret, turizm, sanayi, hizmetler vb. sektörlerde sosyo-ekonomik yapının etkinliğini artırabilecek gelişmelerin olacağı var sayılarak plan hedef yılı olan 2040 yılı nüfusu 6500 kişi olarak kabul edilmiştir (Plan açıklama raporu, 2016).

Çizelge 2. de, 80 li yıllardan itibaren ilçenin her 5 yılda bir nüfusunun logaritmik artış hızı ortaya konarak ortalama nüfusa göre tüm plan donatılarının oluşturulması için nüfus hızı saptanmaya çalışıldı.

Çizelge 3. de, ilçenin korelasyon varyansı doğrultusunda ile ve ülkeye oranla nüfus projeksiyonu hesaplanmış, bu doğrultuda gelecekte oluşacak tüm plan alanlarının oluşmasında kıstas alınacak değerlere bakıldı.

Çizelge 4.de, en küçük karler logaritmik korelasyon bağıntısından ortalama 2035 li yıllara kadar ilçenin nüfus artışının nasıl ne ölçüde olacağı ile ilgili saptamada bulunulmuştur. 
Taşkaya (2021) İZÜ Fen Bilimleri Enstitüsü Dergisi 3 (2)

Çizelge 2. En küçük kareler metodu ile geçmiş yılların nüfus artış hızı (Plan raporu, 2016).

\begin{tabular}{cccccccc}
\hline YILLAR & $\mathbf{x}$ & Nüfus(P) & $\mathbf{x}^{\mathbf{2}}$ & $\mathbf{P} * \mathbf{x}$ & $\log \mathbf{P}$ & $\log \mathbf{P} * \mathbf{x}$ & $\mathbf{r}(\log )$ \\
\hline $\mathbf{1 9 8 0}$ & -3 & 3969 & 9 & -11907 & 3.5987 & -10.7960 & \\
$\mathbf{1 9 8 5}$ & -2 & 4368 & 4 & -8736 & 3.6403 & -7.2806 & 0.0193 \\
$\mathbf{1 9 9 0}$ & -1 & 3957 & 1 & -3957 & 3.5974 & -3.5974 & -0.0196 \\
$\mathbf{1 9 9 5}$ & 0 & 4169 & 0 & 0 & 3.6201 & 0.0000 & 0.0105 \\
$\mathbf{2 0 0 0}$ & 1 & 4393 & 1 & 4393 & 3.6428 & 3.6428 & 0.0105 \\
$\mathbf{2 0 0 5}$ & 2 & 4583 & 4 & 9166 & 3.6611 & 7.3223 & 0.0085 \\
$\mathbf{2 0 1 0}$ & 3 & 4781 & 9 & 14343 & 3.6795 & 11.0386 & 0.0085 \\
Toplam & 0 & 30220 & 28 & 3302 & 25.4398 & 0.3296 & 0.0063 \\
\hline
\end{tabular}

Çizelge 3. Nüfus projeksiyon hesap gösterimi ( Plan raporu, 2016).

\begin{tabular}{|c|c|c|c|c|}
\hline (1) & SELIM (KARS) & $(1980-10)$ & Y1ll1k Nüfus Artış1 r = & 0.00771 \\
\hline (2) & SELİM (KARS) & $(1980-95)$ & Y1ll1k Nüfus Artış1 r = & 0.00329 \\
\hline (3) & İL MERKEZİ (Kentsel) & $(2005-10)$ & Y1llık Nüfus Artış1 r = & -0.01400 \\
\hline \multirow[t]{3}{*}{ (4) } & TÜRKIYE (Toplam) & $(2005-10)$ & Y1llık Nüfus Artış1 r = & 0.01845 \\
\hline & 4360 & $\log (a)=$ & 3.6382 & Korelasyon Katsayıs1 \\
\hline & 147 & $\log (b)=$ & 0.0144 & \\
\hline
\end{tabular}

Çizelge 4. En küçük kareler metodu ile yıllara ait nüfus gösterimi tahmini (Plan raporu, 2016).

\begin{tabular}{cccccccc}
\hline & \multicolumn{7}{c}{ GRAFÍK BíLGíLERİ } \\
& En Küçük Kareler & \multicolumn{7}{c}{ Üssel Artış } \\
\hline Yıllar & Doğrusal & Logaritmik & Faiz & Üssel (1) & Üssel (2) & Üssel (3) & Üssel (4) \\
1980 & 3969 & 3969 & 3969 & 3969 & 3969 & 3969 & 3969 \\
1985 & 4368 & 4368 & 4368 & 4368 & 4368 & 4368 & 4368 \\
1990 & 3957 & 3957 & 3957 & 3957 & 3957 & 3957 & 3957 \\
1995 & 4169 & 4169 & 4169 & 4169 & 4169 & 4169 & 4169 \\
2000 & 4393 & 4393 & 4393 & 4393 & 4393 & 4393 & 4393 \\
2005 & 4583 & 4583 & 4583 & 4583 & 4583 & 4583 & 4583 \\
2010 & 4781 & 4781 & 4781 & 4781 & 4781 & 4781 & 4781 \\
2015 & 4789 & 4801 & 4933 & 4934 & 4860 & 4458 & 5243 \\
2020 & 4907 & 4933 & 5091 & 5092 & 4941 & 4156 & 5750 \\
2025 & 5025 & 5069 & 5253 & 5255 & 5023 & 3875 & 6306 \\
2030 & 5143 & 5208 & 5421 & 5423 & 5106 & 3613 & 6915 \\
2035 & 5261 & 5351 & 5593 & 5596 & 5191 & 3369 & 7584 \\
\hline
\end{tabular}




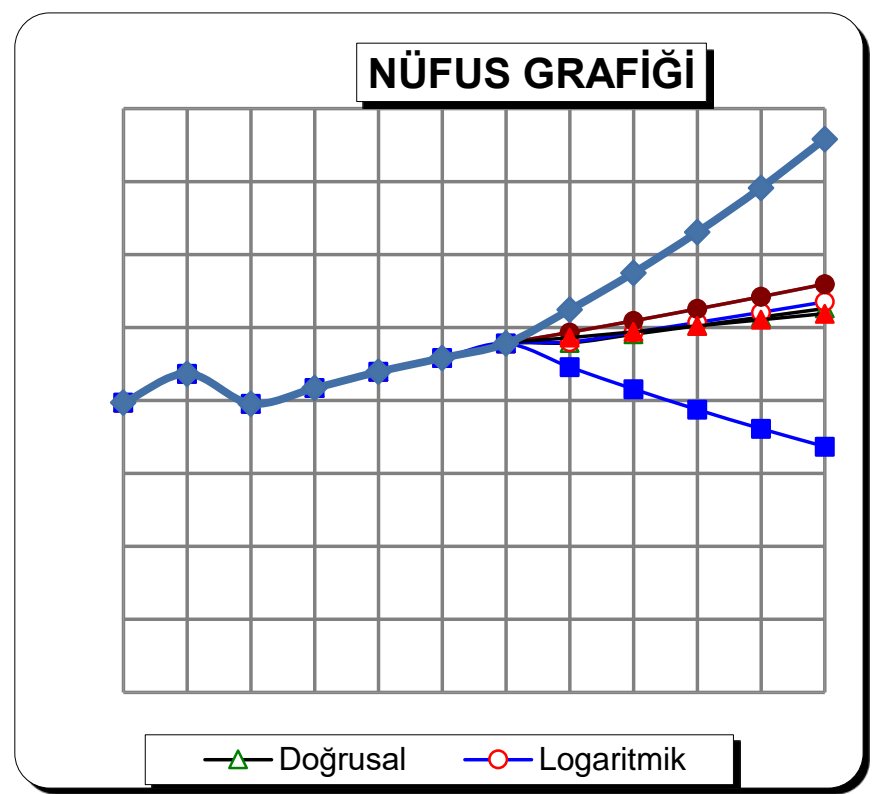

Şekil 1. Nüfusun grafiksel gösterimi (Plan raporu, 2016).

Şekil 1.de, her kare yukarı sütunda 1000 kişi olarak gösterildiğinde grafiksel artış hızı gösterilmeye çalışılmıştır.

\section{Bulgular ve Tartışma}

3.1 Selim İlçesi Eski İmar planı
Selim İlçesi'nin Çevre ve Şehircilik Bakanlığınca yaptırılan ve 03.01.2013 tarihinde onaylanan Ardahan-Kars-Iğdır- Ağrı Planlama Bölgesi 1/100000 Ölçekli Çevre Düzeni Planı bulunmaktadır. Buna göre Selim planlama alanı kentsel yerleşik alan, kentsel gelişme alanı, konut dışı kentsel çalışma alanı, tarım arazisi, organize tarım ve hayvancılık alanı, sulama alanı, çayır-mera ve ağaçlandırılacak alan olarak tanımlanmıştır (Plan raporu, 2016).

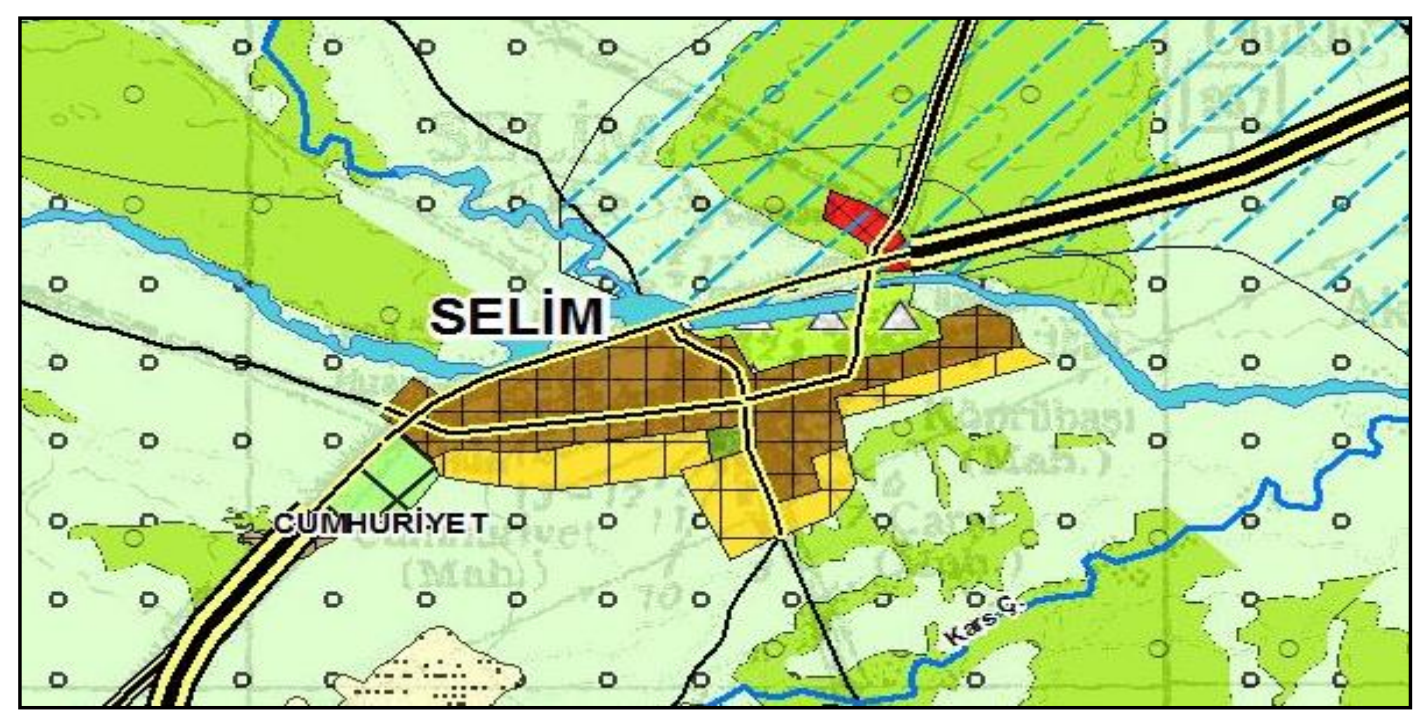

Şekil 2. Ardahan-Kars-Iğdır- Ağrı Planlama Bölgesi 1/100000 Ölçekli Çevre Düzeni Planı (Çevre ve Şehircilik Bakanlığı, 2019).

Selim İlçesi 2010 y1lı şehir nüfusu 4,781, köy nüfusu 19,846 olmak üzere toplam nüfus 24,627 'dir. 2040 yılı şehir nüfusu 6,500, köy nüfusu 24,000 olmak üzere toplam kabul nüfus 30,500 olarak belirlenmiştir. 2040 yılı işgücü projeksiyon kabullerine göre Kars Selim İlçesi'nde; yıllar itibari ile önemli ölçüde değişim göstermeyen tarım(ve hayvancılık) sektöründe çalışan kişi oranı \%85.3 ile yine baskın sektör olmaya devam edecek iken, hizmet sektörünün gelişerek \%12.2'ye, sanayisinin \%1.3'e ve buna bağlı olarak özellikle inşaat sektörü temelli olarak diğer sektörlerin payının \%1.1'e ulaşacağı kabul edilmiştir. Sektörel gelişim açısından; Selim İlçesi'nde tarım sektörünün öncü sektör olarak gelişeceği ve tarım kenti karakterini devam ettireceği kabul edilmiştir (Selim Belediyesi, 2019). 


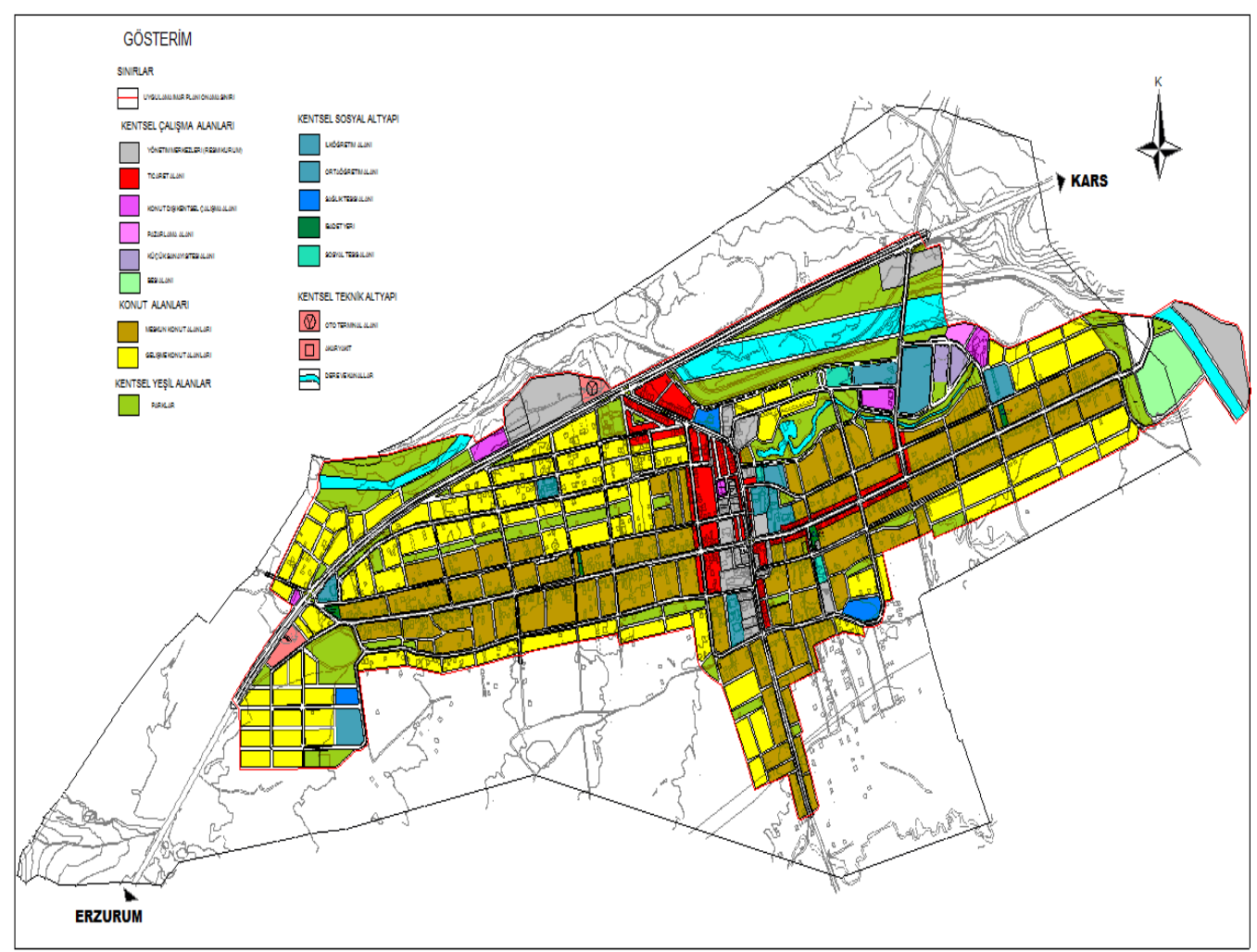

Şekil 3.Eski imar planı (Selim Belediyesi, 2016).

1994 yılında İller Bankası tarafinda onaylanan imar planı ve bu plan üzerinde belediyesi tarafinda yapılan ilave, revizyon ve plan değișiklikleri ile 304 ha alan planlanmıştır. Yapılan çalıșmalarda bu planın yaklaşı \% 30'unda uygulandığı ve bu plan kapsamındaki alanların \% 62'sinin yapılaşmadığı tespit edilmiştir. Yine bu plana aykırı olarak gelişen ve yapılaşan yaklaşık 85 ha'lık bir alan olduğu görülmektedir (Plan raporu, 2016).

Çizelge 5. Eski imar planı alan dağılımı (plan raporu, 2016).

\begin{tabular}{cccc}
\hline Alan Kullanımları & Alan $\left.\mathbf{( m}^{\mathbf{2}}\right)$ & Alan (ha. $)$ & $\begin{array}{c}\text { Toplam Alana Oranı } \\
(\boldsymbol{\%})\end{array}$ \\
\hline Konut Alanları & 1284888.72 & 128.49 & 42.26 \\
Ticaret & 107129.24 & 10.71 & 3.52 \\
Pazar Alanı & 5023.57 & 0.50 & 0.17 \\
KDKÇ & 26819.24 & 2.68 & 0.88 \\
Küçük Sanayi Sitesi & 11073.92 & 1.11 & 0.36 \\
Akaryakıt & 8637.68 & 0.86 & 0.28 \\
Resmi Kurumlar & 156002.43 & 15.60 & 5.13 \\
Eğitim Tesis Alanları & 93210.96 & 9.32 & 3.07 \\
Cami & 6086.54 & 0.61 & 0.2 \\
Sağlı & 18856.79 & 1.89 & 0.62 \\
Spor & 13609.79 & 1.36 & 0.45 \\
Park & 385405.72 & 38.54 & 12.68 \\
Sosyo-kültürel Tesis & 9369.34 & 0.94 & 0.31 \\
Besihaneler & 43228.22 & 4.32 & 1.42 \\
Dere & 140677.50 & 14.07 & 4.63 \\
Yollar & 730569.35 & 73.06 & 24.03 \\
\hline Toplam & 3040589.01 & 304.06 & 100
\end{tabular}

Çizelge 5.de, eski imar planın konut, konut ticari, ticaret, sosyal donatı tüm alanlarının alanı ve toplam imar sınırları içerisindeki alana oranı verilmiştir.
3.2 Selim İlçesi mevcut olacak revize imar planı

Kentin gelişme potansiyelleri ve sektörel dağılımı incelendiğinde gelecekte özellikle ticaret sektöründe gelişim olacağ 1 öngörülmüştür. Ayrıca yerleşmede nitelikli tarım topraklarının bulunması nedeniyle halkın tarıma özendirilerek, tarımda çalışan 
kişilerin bilinçlendirilmesi, gerekli kamu yatırımlarının ve desteklerinin sağlanması sonucu tarım sektörünün etkin bir ekonomik faaliyet alanı olacağı düşüncesi de diğer bir öngörüyü oluşturmaktadır. Sonuç olarak; tüm projeksiyonlar ve üst ölçekli plan kararları göz önünde bulundurularak 2040 yılı planlama nüfusu 6500 kişi kabul edilmiş, planlar doğrultusunda oluşturulacak istihdam olanakları ile 2040 yılı aktivite oranının mevcut orana göre daha yüksek gelișeceği kabul edilerek, \% 42.92 olarak belirlenmiștir (Plan raporu, 2016).

Çizelge 6. Sektörlere Göre çalışanların Mevcut Dağılımı ve Projeksiyonu

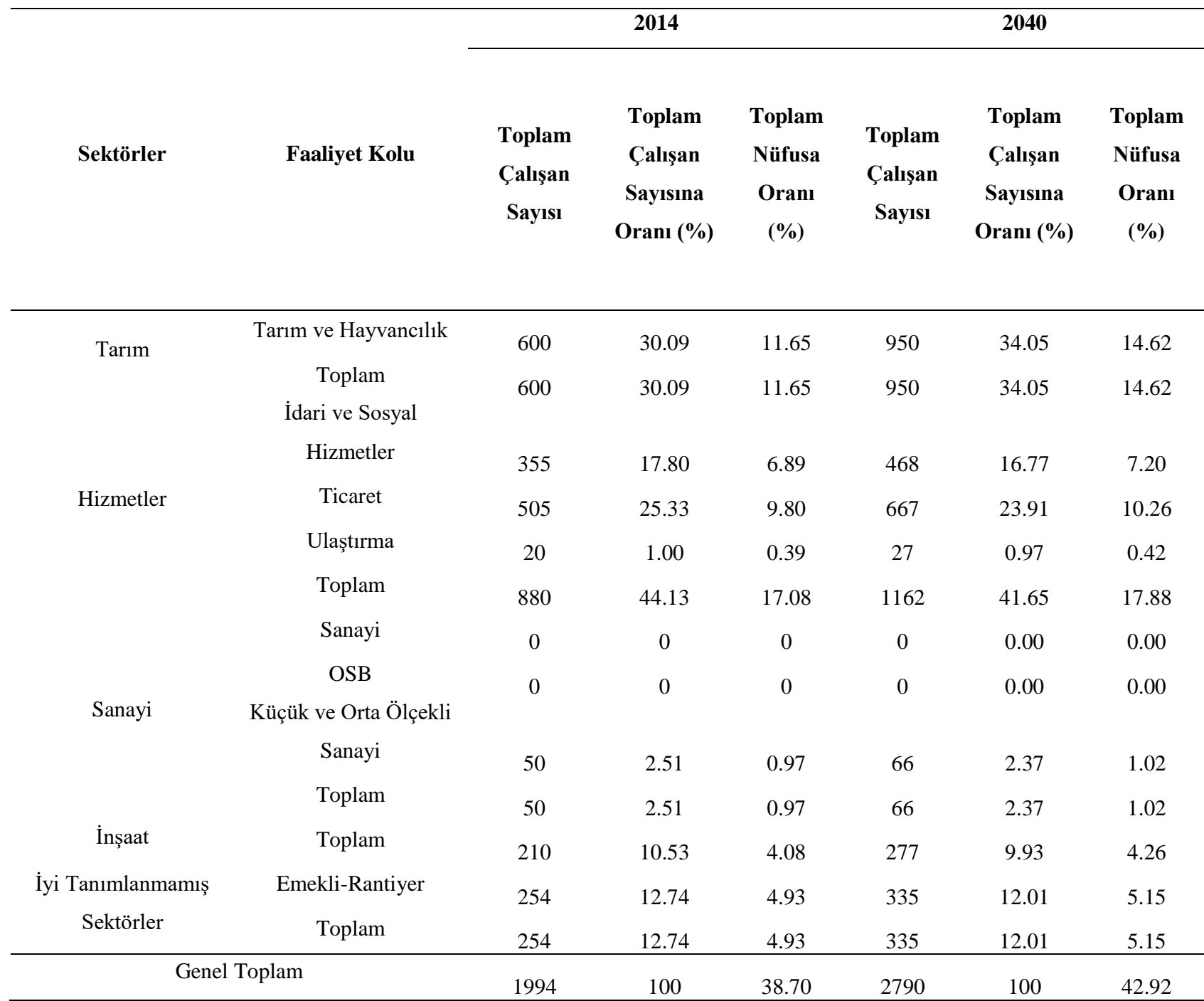

Çizelge 6.da, ilçenin sektörlere göre mevcut durumu incelenmiştir. 
Çizelge 7. Kentsel Alan Kullanım Standartları ve Planlanan Alanlar (Plan raporu, 2016).

\begin{tabular}{|c|c|c|c|c|}
\hline Kentsel Alan Kullanımı & $\begin{array}{l}\text { Standart } \\
\left(\mathbf{m}^{2} / \text { kişi }\right)\end{array}$ & $\begin{array}{l}\text { Standart } \\
\text { Alan }\left(\mathbf{m}^{2}\right)\end{array}$ & Mevcut Alan ( $\left.\mathbf{m}^{2}\right)$ & $\begin{array}{c}\text { İlave Edilmesi } \\
\text { Gereken Alan (m²) }\end{array}$ \\
\hline İlköğretim & 3.00 & & & \\
\hline (İlkokul+ Ortaokul) & $(1.5+1.5)$ & 19500 & 21185 & - \\
\hline Kreş+Ana Okulu & 0.50 & 3250 & 2098 & 1152 \\
\hline $\begin{array}{c}\text { Ortaöğretim } \\
(\text { Lise+YBO+İHL+HalkEğitim) }\end{array}$ & 1.75 & 11375 & 19375 & - \\
\hline Aktif Yeşil Alan & 10 & 65000 & 17233 & 47762 \\
\hline Sağlık Tesisi Alanı & 1.50 & 9750 & 9400 & 350 \\
\hline Sosyal ve Kültürel Tesis Alanları & 0.50 & 3250 & 11570 & 8320 \\
\hline İbadet Yeri & 0.50 & 3250 & 4226 & - \\
\hline Teknik Alt Yapı Alanları & 0.50 & 3250 & 520 & 2730 \\
\hline
\end{tabular}

Çizelge 7.de, Mevcut kullanım alanları ile standartlara göre olması gereken alanlar karşılaştırıldığında en fazla ihtiyaç duyulan alanların açık yeşil alanlar, sağlık tesisleri alanı ile sosyo-kültürel tesis alanları olduğu belirlenmiştir. Eğitim alanlarında aynı binada farklı eğitim birimlerinin yer alabileceği göz önüne alınarak eğitim alanları bütün olarak değerlendirilmiştir. Mevcut Eğitim alanların standartların üzerindedir. Selim ilçesi Eğitim Hizmetleri açısından kendi bölgesinin tümüne hizmet verdiğinden standartların üstünde olması doğaldır. Sağlık tesisleri ve ibadet yeri açısından ilave alana gerek olmadığı görülmektedir.

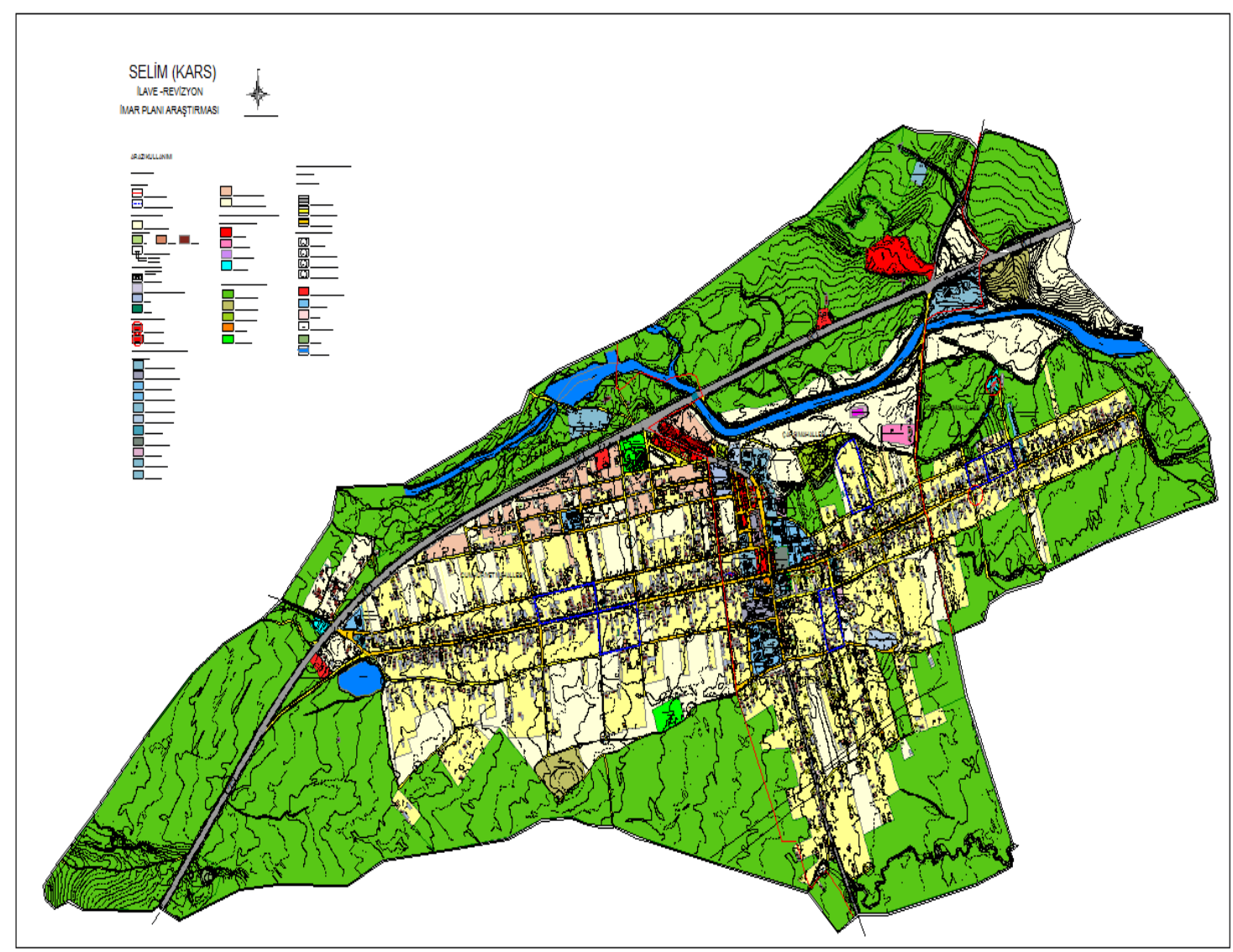

Şekil 4. Bugünkü Arazi Kullanımı

Şekil 4.de, imar sınırları içerisindeki mevcut arazinin kullanım durumu gösterilmiştir. 
Çizelge 8. Bugünkü Arazi kullanım Tablosu

\begin{tabular}{|c|c|c|c|}
\hline Kullanım & Alan (ha) & $\%$ & $\mathbf{m}^{2} / \mathbf{K i s ̧ i}$ \\
\hline Meskun Konut Alanı & 136.32 & 50.93 & 264.60 \\
\hline Ticaret & 6.81 & 2.54 & 13.22 \\
\hline Eğitim Alanları & 4.26 & 1.59 & 8.27 \\
\hline Sağlık & 0.94 & 0.35 & 1.82 \\
\hline Resmi Kurum & 6.46 & 2.41 & 12.54 \\
\hline Belediye Hizmet Alanı & 1.19 & 0.44 & 2.31 \\
\hline Sosyal Tesis Alanı & 1.16 & 0.43 & 2.25 \\
\hline Kültürel Tesis Alanı & 0.23 & 0.09 & 0.45 \\
\hline Dini Tesis & 0.42 & 0.16 & 0.82 \\
\hline Spor Alanı & 2.09 & 0.78 & 4.06 \\
\hline Askeri Alan & 0.61 & 0.23 & 1.18 \\
\hline Terminal & 0.77 & 0.29 & 1.49 \\
\hline Park & 1.72 & 0.64 & 3.34 \\
\hline Mezarlık & 4.54 & 1.70 & 8.81 \\
\hline İfrazsız Alanlar & 8.21 & 3.07 & 15.94 \\
\hline İfrazsız Alanlar & 73.07 & 27.30 & 141.83 \\
\hline Yol-Otopark & 16.92 & 6.32 & 32.84 \\
\hline Lojman & 1.86 & 0.69 & 3.61 \\
\hline Teknik Alt Yapı Alanı & 0.10 & 0.04 & 0.19 \\
\hline Kentsel Alan Toplamı 1/1000 & 267.68 & 100.00 & 519.57 \\
\hline Tarım Alanı & 300.22 & & \\
\hline Dere & 12.11 & & \\
\hline Akaryakıt İstasyonu & 1.07 & & \\
\hline Yollar & 10.51 & & \\
\hline Kentsel Alan Çevresi Toplamı & 323.91 & & \\
\hline Genel Toplam (1/5000) & 591.59 & & \\
\hline
\end{tabular}

Cizelge 8.de, Selim merkez yerleşiminin mevcut nüfusu 5152 (2014) kişi olup, yapılan nüfus projeksiyonları ortalamasına göre 2030 yılı nüfusu yaklaşık 5261 kişi çıkmaktadır. Onanlı Çevre Düzeni Planı ile Selim ilçesi için öngörülen 2040 yılı için şehir nüfusu 6500 kişi olarak belirlenmiştir. Plan dönemi içerisinde ticaret, tarımhayvancılık, hizmetler vb. sektörlerde sosyo-ekonomik yapının dinamizmini artırabilecek gelişmelerin olacağı göz önüne alınarak üst ölçekli plan kararları doğrultusunda plan nüfusu 6500 kişi olarak kabul edilmiştir (Plan raporu, 2016).

Mevcut imar planının aksayan yönleri revize edilmiş, mekansal projeksiyonlarla elde edilen sosyal donatı alanları kent bütününe hizmet verecek şekilde dağıtılmıştır. Kentsel gelişmeyi sınırlayıcı yönde eşik teşkil eden, mutlak tarım alanları korunmuştur. Planın uygulanabilirliğinin artması için belediyenin istekleri dikkate alınmıștır. Sosyal donatı ve açık-yeșil alan eksikliğini gidermek üzere kentsel standartlara uygun yeterli donatı ve yeşil ayrılmıştır. Üst ölçekli plan kararları ve kurum görüşleri doğrultusunda 1/5000 ölçekli nazım imar planı onaylı halihazır harita bütününde hazırlanmıştır. Çevre düzeni planında Konut dışı Kentsel Çalışma alanı olarak tanımlanan alanlar toprak etüdüyle mera alanı olarak gösterildiğinden ve bir kısmı da orman görüşünde ağaçlandırma sahasında kaldığından konut dışı kentsel çalışma alanları karayolunun güneyine kaydırılmıştır. DSİ etüdüne göre ıslah edilecek kekeç deresi ile karayolu arasında kalan bölgede planlanmıștır. Orman görüşünde belirlenen ağaçlandırılacak alanlar planlara işlenmiş. Bu bölgedeki mevcuttaki cezaevi korunmuştur. Üst ölçekli plan kararları ile Sarıkamış yolu üzerinde Cumhuriyet Köyü olarak belirlenen alanın yakınına Organize Tarım/ Hayvancılık Alanı önerilmiştir. Ancak söz konusu alanın bir kısmının belediyesinin ilave imar planı ile konut alanı olarak planlandığı, bir kısmı ise tarım etüdüyle mutlak tarım alanı olarak belirlendiğinden mutlak tarım alanları dışında kalan alanlar Organize Tarım / Hayvancılık Alanı olarak planlanmıştır. Ayrıca Cumhuriyet Köyünün yerleşim alanının Çevre düzeni planına sehven farklı bir alanda işlendiği tespit edildiğinden söz konusu alan küçük sanayi sitesi alanı olarak planlanmıştır (Plan raporu, 2016). 
Çizelge 9. Selim Farklı Yoğunluk Bölgelerinde Parsel Sayıları ve Nüfus

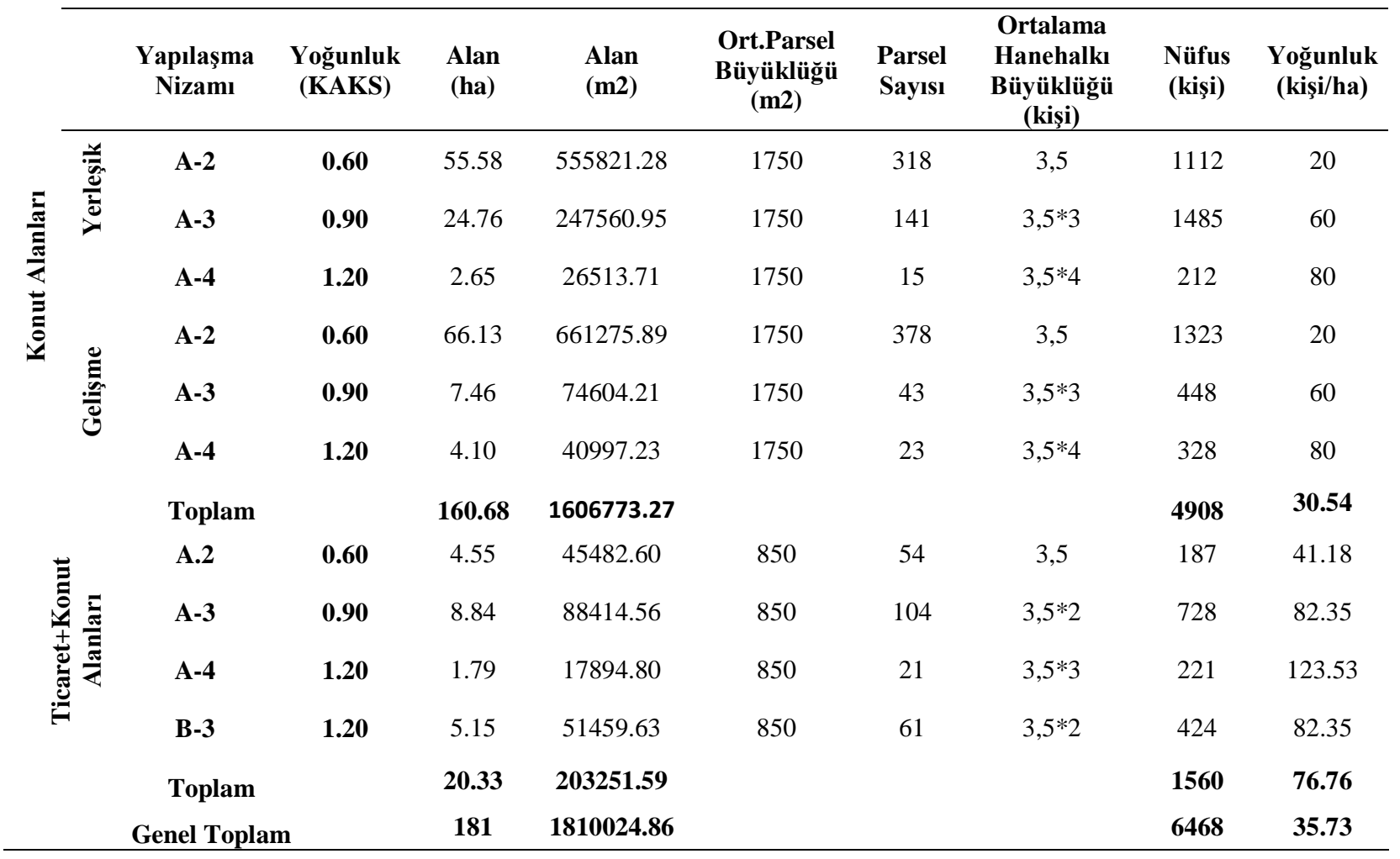

Çizelge 9.da, Selim yerleşmesinde yer alan konut alanları çoğunlukla tek katlı binalardan oluşmaktadır. Belediye çevresinde yer yer alt katları ticaret kullanımında olan 3 katlı yapılar ve kentin ana giriş kapısı konumunda olan kuzey girişi üzerinde konut altı ticaret şeklinde oluşmuş 4 katlı betonarme yapılar görülmektedir. Yerleşmede mevcut ve öneri konut alanlarında Ayrık nizam 2, 3 ve 4 kat ve Bitişik nizam 3 kat arasında değişen kat yükseklikleri ile 0.60 ve 1.20 arasında değişen yapı yoğunlukları önerilmiştir. Konut artı ticaret alanlarında Ayrık nizan 2 kat, Bitişik nizam 3 kat ve 1.20 ve 0.60 arasında değişen yapı yoğunlukları verilmiştir. Ayrık nizam iki katlı alanlarda parselde 1 ailenin yaşayacağı ve ortalama parsel büyüklüğünün $1750 \mathrm{~m}^{2}$ olacağı var sayılmıştır. Ayrık nizam üç katlı alanlarda parselde 3 ailenin, dört katlı alanlarda parselde 4 ailenin yaşayacağı ve ortalama parsel büyüklüğünün $1750 \mathrm{~m}^{2}$ olacağı var sayılmıştırTicaret+konut olarak önerilen yapı adalarında Alt katların ticaret, üst katların konut olacağı varsayımı ile ticaret+konut bölgelerinin üst katları konut alanı olarak nüfus hesaplamalarına dahil edilmiştir. Konut Artı Ticaret olarak belirlenen yapı adalarında ortalama parsel büyüklüğü $850 \mathrm{~m}^{2}$ olarak kabul edilmiştir (Plan raporu, 2016). 
Çizelge 10. Selim (Kars) İmar Planı Alan Kullanım Tablosu (2040) (Selim Belediyesi, 2019).

\begin{tabular}{|c|c|c|c|c|}
\hline Alan Kullanımları & $\operatorname{Alan}\left(\mathbf{m}^{2}\right)$ & Alan (ha) & Oran $(\%)$ & Alan/kişi (m²/kişi) \\
\hline Meskun Konut Alanı & 829895.94 & 82.99 & 21.93 & 127.68 \\
\hline Gelişme Konut Alanı & 776877.33 & 77.69 & 20.53 & 119.52 \\
\hline Ticaret Alanı & 36132.12 & 3.61 & 0.95 & 5.56 \\
\hline Ticaret - Konut Alanı & 203631.50 & 20.36 & 5.38 & 31.33 \\
\hline Ticaret - Turizm Alanı & 32472.66 & 3.25 & 0.86 & 5.00 \\
\hline Anaokul Alanı & 1725.57 & 0.17 & 0.05 & 0.27 \\
\hline İlkokul Alanı & 51593.13 & 5.16 & 1.36 & 7.94 \\
\hline Ortaokul Alanı & 42240.07 & 4.22 & 1.12 & 6.50 \\
\hline Lise Alanı & 11412.47 & 1.14 & 0.30 & 1.76 \\
\hline Askeri Alan(Jandarma) & 13549.87 & 1.35 & 0.36 & 2.08 \\
\hline Resmi Kurum Alanı & 73195.74 & 7.32 & 1.93 & 11.26 \\
\hline Belediye Hizmet Alanı & 47641.90 & 4.76 & 1.26 & 7.33 \\
\hline Sağlık Tesisi Alanı & 15941.49 & 1.59 & 0.42 & 2.45 \\
\hline Sosyal Tesis Alanı & 4928.08 & 0.49 & 0.13 & 0.76 \\
\hline Kültürel Tesis Alanı & 9550.26 & 0.96 & 0.25 & 1.47 \\
\hline Halk Eğitim Merkezi & 2067.20 & 0.21 & 0.05 & 0.32 \\
\hline Yurt Alanı & 11309.51 & 1.13 & 0.30 & 1.74 \\
\hline Spor Alanı & 34339.09 & 3.43 & 0.91 & 5.28 \\
\hline İbadet Alanı & 9376.59 & 0.94 & 0.25 & 1.44 \\
\hline Park & 261314.50 & 26.13 & 6.91 & 40.20 \\
\hline Çocuk Bahçesi & 10126.56 & 1.01 & 0.27 & 1.56 \\
\hline Rekrasyon Alanı & 102187.29 & 10.22 & 2.70 & 15.72 \\
\hline Toplu İşyerleri & 9440.00 & 0.94 & 0.25 & 1.45 \\
\hline Pazar Alanı & 4482.82 & 0.45 & 0.12 & 0.69 \\
\hline Tarım ve Hayvancılık Tesis Alanı & 9469.04 & 0.95 & 0.25 & 1.46 \\
\hline Akaryakıt ve Servis İstasyonu & 8492.98 & 0.85 & 0.22 & 1.31 \\
\hline Terminal(Otogar) & 8440.50 & 0.84 & 0.22 & 1.30 \\
\hline Yol (Karayolu 17.78 ha.) & 953435.97 & 95.34 & 25.20 & 146.68 \\
\hline Teknik Altyapı Alanı & 36733.05 & 3.67 & 0.97 & 5.65 \\
\hline $\begin{array}{c}\text { Mezarlık } \\
\text { Yenilenebilir Enerii Kaynaklarına Dayalı }\end{array}$ & 20301.46 & 2.03 & 0.54 & 3.12 \\
\hline Üretim Tesisi Alanı & 71405.60 & 7.14 & 1.89 & 10.99 \\
\hline Dere & 80407.20 & 8.04 & 2.12 & 12.37 \\
\hline Toplam (1/1000) & 3784117.49 & 378.41 & 100 & \\
\hline Kentsel Alan Kullanımı & 3784117.49 & 378.41 & 63.48 & \\
\hline Cezaevi Alanı & 3545.94 & 0.35 & 0.06 & \\
\hline Küçük Sanayi Alanı & 22736.56 & 2.27 & 0.38 & \\
\hline Mutlak Tarım Alanları & 882912.02 & 88.29 & 14.81 & \\
\hline Doğal Karakteri Korunacak Alanlar & 290836.86 & 29.08 & 4.88 & \\
\hline Ağaçlandırılacak Alanlar & 191684.44 & 19.17 & 3.22 & \\
\hline Mera Alanları & 515908.54 & 51.59 & 8.65 & \\
\hline Organize Tarım ve Hayvancılık Alanı & 80468.56 & 8.05 & 1.35 & \\
\hline Dere & 47367.24 & 4.74 & 0.79 & \\
\hline Yol (Karayolu 6.99 ha.) & 141754.9 & 14.18 & 2.38 & \\
\hline Toplam (1/5000) & 5961332.55 & 596.13 & 100 & \\
\hline
\end{tabular}

Çizelge 10.da, 3194 sayılı kanun kapsamında bir plan yapılırken bulunması ve yapılması gereken tüm alanlar en küçük kareler yöntemi ile hesaplanan nüfus projeksiyonuna göre dağılımı yapılmıştır. 


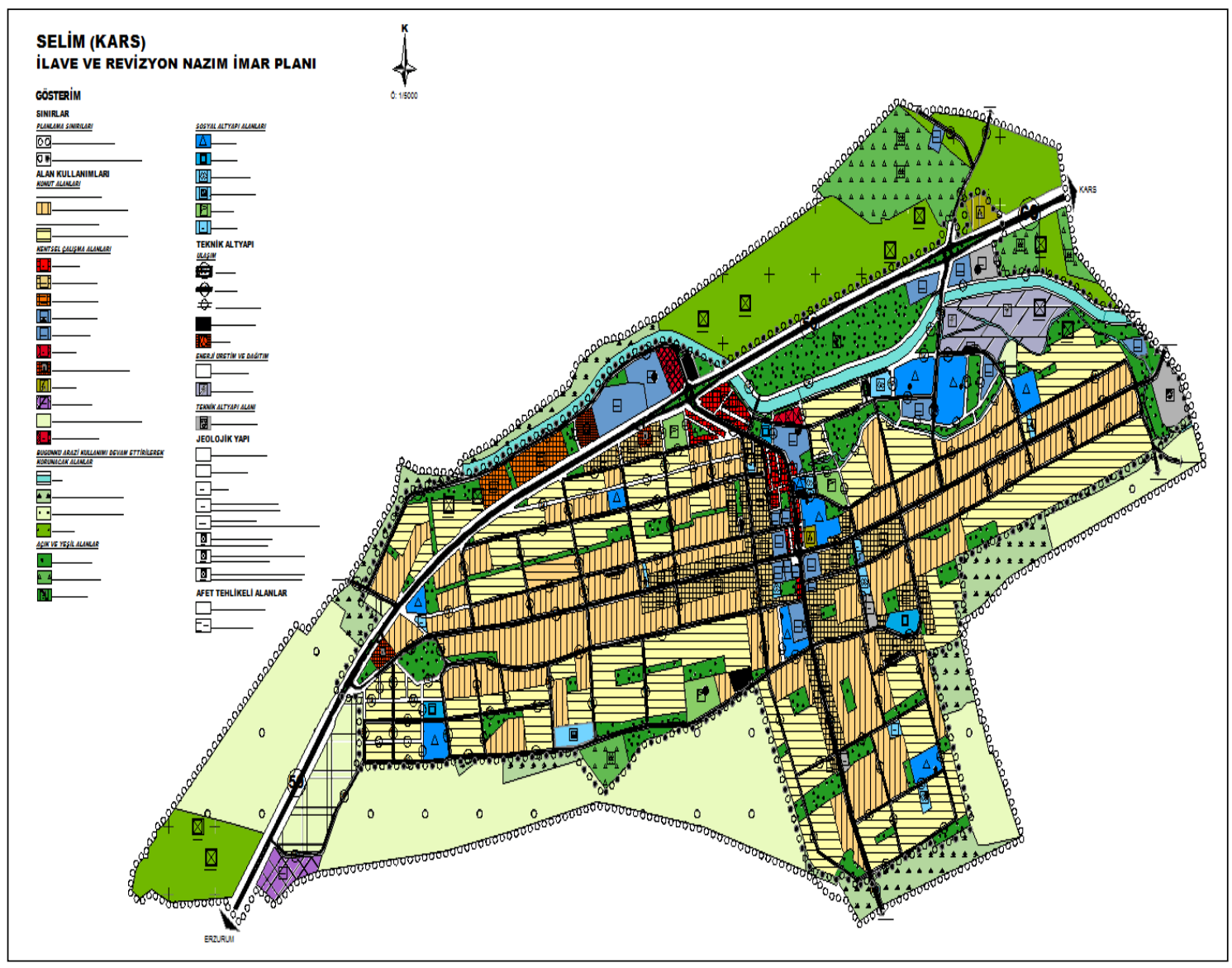

Şekil 5. Yürürlükte olacak 2040 yılına kadar kullanılacak imar planı (Plan raporu, 2019).

Öneri nazım imar planı ile toplam 596 ha. alan planlanmıştır. Nazım imar planı doğrultusunda bütünsel olarak hazırlanan 1/1000 ölçekli uygulama imar planı ile 378.41 ha alan planlanmıştır. Planlanan toplam 160.68 ha konut ve 20.33 ha konut art1 ticaret alanında toplam 6500 kişinin yaşayacağı ön görülmüştür (Plan raporu, 2016).

\section{Sonuç}

Revize imar planları, mevcut duruma ait imar planının ihtiyaca cevap verecek durumu kaybettiği hallerde imar planını iyileştirme çalışmalarıdır. Çalışmamızda. Basit şekilde nüfusu ortalama olan Selim ilçesi üzerinden nüfus projeksiyonu en küçük kareler yöntemi ile varsayımsal regrasyon olarak hesaplanıp ortalama olarak ortaya kondu. $\mathrm{Bu}$ nüfus olası durumunda 30-40 yıl boyunca ilçenin Kars İlinin hangi yönüne nasıl gelişmesine göre konut ticaret yeşil alan oranları belirlendi. Eski imar planında genellikle ayrık 2 ve 3 kat durumunda olana imar adalarının 4 kat çıkarılması, bitişik nizam yapılaşmanın ve ticari alanlarının yapı iznine geçilmesine karar verilmiștir. Tarım arazileri, akaryakıt alanları, vb. alanlarının oranları artırıldı. Bu tip revize planlarının nasıl hangi parametrelere dayanarak yapılması gerekliliği ortaya kondu.

\section{Teşekkür}

Artvin Ardanuç Tapu ve Kadastro Mezun Öğrencisi Selim İlçeli Oğuzhan Şentürk'e araştırma ile ilgili katkılarından dolayı teşekkür ederim.

\section{Kaynaklar}

Aydemir Şinasi, Aydemır Saliha, Beyazlı Dilek, Ökten Nermin, Öksüz M. Ahmet, Sancar Cenap, Özyaba Murat, Türk
Yelda, “Kentsel Alanların Planlanması Ve Tasarımı", İber Matbaacilik, Trabzon, 2004.

Suher Hande, Şehircilik, İtü Baskı Atelyesi, İstanbul, 1996.

Emre Gülaç. İmar Planlarının Uygulanabilirliği; Van Kenti Örneği, Yüksek Lisans Tezi, 2015.

Selda Karaman, İmar Planı Değişiklikleri Konusunda Muğla/Yalıkavak Örneği Üzerine Bir İnceleme, Yüksek Lisans Tezi, 2012.

Doğan Ertuğrul Ve Ergġngöz M. Aykaç (1997), Türkiye'de Kıyı Alanları Yönetimi Ve Yapılaşması, İstanbul: Arıon Yayınevi.

Tazegül, İsmail, "Kent Ölçekli Planlama Ve Uygulamada Karşılașlan "Korunlar", Http://Www.Yayin.Adalet.Gov.Tr/Dergi/36.Say\%C4\%B1/I smailtazeg\%C3\%Bcl.Pdf (09.12.2010).

Fırat Demir, İki Aşamalı En Küçük Kareler Yöntemi Ve Uygulamas1, Yüksek Lisans Tezi, 2019.

İller Bankası Anonim Şirketimekansal Planlama Dairesi Başkanlığı Selim (Kars)İlave - Revizyon İmar Planı İmar Planı Açıklama Raporu, 2016.

Montgomery Dc, Peck Ea. Introduction To Linear Regression Analysis. John Wiley\&Sons, Inc, Canada. 1992:85-120.

Türkiye İstatistik Kurumu, 2019.

Çevre Ve Şehircilik Bakanlığ $1,2019$.

Selim Belediyesi, 2019. 